\title{
TINGKAT PARTISIPASI ANGGOTA DALAM \\ PROGRAM OPTIMALISASI PEMANFAATAN LAHAN PEKARANGAN \\ MELALUI KONSEP KAWASAN RUMAH PANGAN LESTARI \\ (Studi Kasus di KWT Mekarwangi Desa Mekarmulya Kecamatan Pamarican Kabupaten Ciamis)
}

\author{
BAYU ROHMATULLOH ${ }^{{ }^{*}}$, DINI ROCHDIANI ${ }^{2}$, SUDRAJAT $^{1}$ \\ ${ }^{1}$ Fakultas Pertanian Universitas Galuh \\ ${ }^{2}$ Fakultas Pertanian Universitas Padjajaran \\ Email : byrohmatulloh@gmail.com
}

\begin{abstract}
ABSTRAK
Penelitian ini bertujuan untuk mengetahui karakteristik responden, tingkat partisipasi anggota, dan hubungan karakteristik responden dengan tingkat partisipasi dalam program Optimalisasi Pemanfaatan Lahan Pekarangan Melalui Konsep Kawasan Rumah Pangan Lestari. Metode penelitian yang digunakan dalam penelitian ini adalah metode studi kasus. Penarikan sampel dilakukan secara sensus pada seluruh anggota kelompok wanita tani (KWT) Mekarwangi yang berjumlah 30 orang. Analisis data dilakukan secara deskriptif. Hasil penelitian menunjukkan bahwa anggota Anggota Kelompok wanita Tani (KWT) Mekarwangi Desa Mekarmulya memiliki karakteristik yaitu; mayoritas berusia diantara 30 - 50 tahun (dewasa pertengahan) termasuk kategori sedang, tingkat pendidikan anggota sebagian besar telah menempuh Pendidikan Dasar (SD/MI,SMP/MTs) termasuk kategori rendah, jumlah tanggungan sebagian besar antara $2-3$ orang termasuk kategori rendah, dan status atau jabatan dalam Kelompok Wanita Tani (KWT) Mekarwangi ada dua kategori jabatan yaitu sebagai anggota dan sebagai pengurus. Tingkat partisipasi pada tahap pengambilan keputusan termasuk dalam kategori sedang, sementara pada tahap pelaksanaan, menikmati hasil dan tahap evaluasi termasuk dalam kategori tinggi. Karakteristik responden yaitu usia, tingkat pendidikan, jumlah tanggungan keluarga dan status tidak memiliki hubungan nyata dengan tingkat partisipasi dalam Program Optimalisasi Pemanfaatan Pekarangan melalui Konsep kawasan Rumah Pangan Lestari.
\end{abstract}

Kata Kunci : Kelompok wanita Tani (KWT), Karakteristik, Partisipasi

\section{PENDAHULUAN}

Program Optimalisasi Pemanfaatan

Lahan Pekarangan melalui Konsep

Kawasan Rumah Pangan Lestari, dalam rangka mempercepat diversifikasi pangan dan memperkuat ketahanan pangan masyarakat. Program ini menitikberatkan pada pemberdayaan masyarakat dalam hal ini adalah wanita tani. Di Kecamatan Pamarican terdapat Kelompok Wanita Tani (KWT) yang menjadi pelaksana Program tersebut yaitu Kelompok Wanita Tani (KWT) Mekarwangi yang berlokasi di Desa Mekarmulya. Sebagai program pem- berdayaan masyarakat, dalam penyelenggaraannya Program ini memerlukan partisipasi masyarakat agar program tersebut berjalan dengan baik dan mencapai keberhasilan sesuai dengan tujuan program. Dengan demikian masyarakat yang menja- lankan program tersebut diharapkaan dapat berperan aktif mulai dari tahap perencanaan, pelaksanaan, menikmati hasil, dan evaluasi. 


\section{METODE PENELITIAN}

\section{Jenis Penelitian}

Penelitian ini dilaksanakan dengan menggunakan metode studi kasus dengan mengambil kasus pada Kelompok Wanita Tani (KWT) "Mekarwangi" di Desa Mekarmulya Kecamatan Pamarican Kabupaten Ciamis.

\section{Operasionalisasi Variabel}

Variabel yang diamati dalam penelitian ini diopreasionalisasikan sebagai berikut:

1. Karakteristik responden, merupakan faktor yang berasal dari diri responden dan dapat mempengaruhi tingkat partisipasi. Adapun karakteristik yang dimaksud adalah usia, tingkat pendidikan dan jumlah tanggungan keluarga.

a. Usia, adalah selisih antara tahun responden dilahirkan dengan tahun saat penelitian ini dilaksanakan. Pengelompokkan usia menurut Havighurst (1950) dalam Mugniesyah (2006) yaitu dewasa awal berusia 18 - 29 tahun, usia pertengahan berusia 30 - 50 tahun, dan usia tua berusia lebih dari 50 tahun, diukur dengan skoring.

b. Tingkat pendidikan, adalah pendidikan formal terakhir yang pernah ditempuh responden hingga penelitian dilaksanakan, diukur dengan skoring.

c. Tanggungan keluarga, adalah banyaknya anggota keluarga yang terdiri dari suami, istri, anak, serta orang lain yang turut serta dalam keluarga dan menjadi tanggungan kepala keluarga, diukur dengan skoring.

d. Status atau jabatan, adalah jabatan yang dimiliki oleh responden saat dilakukannya penelitian ini. Dalam kelompok wanita tani (KWT) Mekarwangi ada dua kategori jabatan yaitu sebagai anggota dan sebagai pengurus.

2. Tingkat partisipasi anggota adalah kewajiban atau kontribusi yang diberikan anggota kelompok dalam kegiatan Optimalisasi Pemanfaatan Lahan Pekarangan Melalui Konsep Kawasan Rumah Pangan Lestari dalam hal ini meliputi :

a. Partisipasi dalam pengambilan keputusan, dilihat dari keikutsertaan petani dalam mengikuti kegiatan penyusunan rencana kegiatan, penentuan alternatif yang berkaitan dengan gagasan atau ide yang 
menyangkut kepentingan bersama, diukur dengan skoring.

b. Partisipasi dalam pelaksanaan kegiatan, dilihat dari keikutsertaan anggota kelompok dalam pelaksanaan kegiatan, diukur dengan skoring.

c. Partisipasi dalam menikmati hasil, dilihat dari keikutsertaan anggota kelompok dalam memanfaatkan dan menikmati hasil setelah berpartisipasi dalam kegiatan, diukur dengan skoring.

d. Partisipasi dalam evaluasi, dilihat literatur yang berkaitan dengan penelitian seperti buku, jurnal, laporan hasil penelitian, publikasi BPS, skripsi, dan internet.

\section{Teknik Penarikan Sampel}

Penarikan sampel dalam penelitian ini yaitu dilakukan secara sengaja (Purposive) yaitu dengan mengambil seluruh (sensus) anggota populasi wanita tani pada kelompok wanita tani (KWT) Mekarwangi dengan jumlah anggota sebanyak 30 orang untuk dijadikan responden.

\section{Rancangan Analisis Data}

Data yang diperoleh dari dari lapangan dianalisis secara deskriptif kualitatif. Untuk mengetahui tingkat partisipasi anggota dibagi kedalam tiga kategori, dengan panjang kelas interval untuk setiap kategori dihitung dengan rumus (Sudjana, 2005) : dari keikutsertaan atau kehadiran responden dalam memantau dan menilai kegiatan yang sudah dilaksanakan, diukur dengan skoring.

\section{Teknik Pengumpulan Data}

Data yang dikumpulkan dan berhubungan dengan penelitian ini adalah data primer dan data sekunder. Data primer diperoleh langsung dari anggota kelompok wanita tani (KWT) dimana semua anggota dijadikan sebagai responden yang diperoleh dengan menggunakan kuesioner. Data sekunder yaitu data yang diperoleh dari dinas atau instansi terkait dari literatur-

Untuk menganalisis hubungan antara karakteristik responden dengan tingkat partisipasi dianalisis dengan menggunakan analisis Rank Spearman untuk dua variabel berskala ordinal. Analisis data secara kuantitatif diolah dan disajikan menggunakan aplikasi SPSS.

\section{Tempat dan Waktu Penelitian}

Penelitian ini dilaksanakan di Kelompok Wanita Tani (KWT) Mekarwangi Desa Mekarmulya Kecamatan Pamarican Kabupaten Ciamis. Penelitian Ini Dilaksanakan Dalam Beberapa Tahap Yaitu : 
1. Tahap Pendahuluan, Yaitu Survai Pendahuluan Penulisan Usulan Penelitian Dan Seminar Usulan Penelitian Dilaksanakan Pada Bulan Pebruari 2019.

2. Tahap Pengumpulan Data Dari Lapangan Atau Pelaksanaan Penelitian Dilakukan Pada Bulan April Sampai Juni 2019.

3. Tahap Pengolahan Data Dan Penulisan Hasil Penelitian Dilaksanakan Pada Bulan Juli 2019

4. Sampai Dengan Selesai.

\section{HASIL DAN PEMBAHASAN A.}

\section{Karakteristik Responden}

Karakteristik responden yang d igunakan dalam penelitian ini adalah usia, tingkat pendidikan, dan jumlah tanggungan keluarga.

\section{Usia}

Mayoritas responden berada pada usia 30 - 50 tahun yaitu 20 atau 66,67 persen, usia 18 - 29 tahun 7 orang atau 23,33 persen, dan pada usia $>50$ tahun 3 orang atau 10,00 persen. Hal ini menunjukkan bahwa yang lebih dominan mengikuti Program Optimalisasi Pemanfaatan Pekarangan Melalui Konsep Kawasan rumah Pangan Lestari adalah anggota yang tergolong berusia dewasa pertengahan (30 - 50 tahun) yaitu 66,67 persen.

\section{Tingkat Pendidikan}

Tingkat pendidikan pada kategori rendah dengan jumlah 27 orang atau 90,00 persen, kemudian pada tingkat pendidikan yang sedang 2 orang atau

6,67 persen, dan pada tingkat pendidikan tinggi 1 orang atau 3,33 persen. Hal ini menunjukkan bahwa tingkat pendidikan responden mayoritas adalah lulus pendidikan dasar (SD/MI,SMP/MTs). Rendahnya tingkat pendidikan responden tentu akan berpengaruh pada pola pikir dan pola kerja mereka dalam Kelompok Wanita Tani (KWT).

\section{Tanggungan Keluarga}

Mayoritas responden memiliki jumlah tanggungan keluarga $4-5$ orang yaitu 17 orang atau 56,67 persen, sedangkan jumlah tanggungan keluarga

2 - 3 orang 12 orang atau 40,00 persen, kemudian untuk responden yang memiliki jumlah tanggungan keluarga $6-8$ orang 1 orang persentase 3,33 persen.

\section{Status /Jabatan}

Jumlah responden dengan status sebagai anggota 23 orang dari 30 orang responden yang diteliti atau 76,67 persen. Kemudian responden dengan status sebagai pengurus 
KWT Mekarwangi 7 orang atau 23,33 persen.

\section{B. Tingkat Partisipasi}

Tingkat partisipasi anggota adalah kewajiban atau kontribusi yang diberikan anggota kelompok dalam kegiatan Optimalisasi Pemanfaatan Lahan Pekarangan Melalui Konsep Kawasan Rumah Pangan Lestari dalam hal ini meliputi : 1) partisipasi dalam pengambilan keputusan; 2) partisipasi dalam pelaksanaan; 3) partisipasi dalam Menikmati hasil; dan 4) partisipasi dalam evaluasi.

\section{Partisipasi dalam Pengambilan}

\section{Keputusan}

Tingkat partisipasi anggota pada tahap pengambilan keputusan, mayoritas berada pada kategori tinggi yaitu dengan jumlah 11 orang dari 30 orang responden yang diteliti atau

36,67 persen, kemudian pada kategori sedang terdapat 10 atau 33,33 persen, sementara kategori rendah terdapat 9 atau 30,00 persen. Hal ini dapat dilihat bahwa anggota aktif mengikuti rapat perencanaan dan berpartisipasi dalam memberikan pendapat, pertanyaan maupun kritik dalam rapat tersebut.

\section{Partisipasi dalam Pelaksanaan}

Tingkat partisipasi anggota dalam pelaksanaan, mayoritas berada pada kategori tinggi yaitu dengan jumlah 23 orang dari 30 orang responden yang diteliti atau 76,67 persen. Kemudian pada kategori sedang terdapat 7 orang dari 30 orang atau 23,33 persen dan tidak ada satupun anggota dengan tingkat partisipasi pada kategori rendah. Hal ini dapat terjadi karena mayoritas anggota antusias dan tertarik untuk berpartisipasi aktif pada setiap kegiatan.

\section{Partisipasi dalam Menikmati}

\section{Hasil}

Tingkat partisipasi anggota dalam menikmati hasil, mayoritas berada pada kategori tinggi yaitu dengan jumlah 23 orang atau 76,67 persen. Kemudian pada kategori sedang terdapat 7 orang atau 23,33 persen dan tidak ada satupun anggota dengan tingkat partisipasi pada kategori rendah. Hal ini dapat terjadi karena mayoritas anggota mengaku merasakan menerima manfaat dari adanya program tersebut.

\section{Partisipasi dalam Evaluasi}

Tingkat partisipasi anggota dalam evaluasi, mayoritas berada pada kategori tinggi yaitu dengan jumlah 25 orang atau 83,33 persen. Kemudian pada kategori sedang terdapat 5 orang atau 16,67 persen dan tidak ada satupun anggota dengan tingkat partisipasi pada kategori rendah. 
Hal ini dapat terjadi karena mayoritas anggota merasakan pentingnya melakukan evaluasi, ini diwujudkan dengan kehadiran anggota dalam rapat evaluasi yang diadakan.

\section{Tingkat Partisipasi Keseluruhan}

Tingkat partisipasi anggota dalam

Program Optimalisasi Lahan Pekarangan

Melalui Konsep Kawasan Rumah Pangan

Lestari mayoritas berada pada kategori tinggi yaitu 16 orang dari 30 orang responden yang diteliti 53,33 persen. Kemudian pada kategori sedang 14 orang atau 46,67 persen, dan tidak ada satupun anggota dengan tingkat partisipasi pada kategori rendah. Hal ini terjadi karena responden mayoritas aktif pada setiap tahapan partisipasi mulai dari tahap pengambilan keputusan, pelaksanaan, menikmati hasil dan evaluasi. Selain itu juga karena responden antusias dalam melaksanakan program optimlaisasi lahan melalui pemanfaatan pekarangan dengan konsep kawasan rumah pangan lestari tersebut.

\section{Hubungan Karakterisktik}

\section{Responden dengan Tingkat Partisipasi}

Faktor yang dapat mempengaruhi partisipasi ada yang berasal dari dalam atau faktor internal da nada juga yang berasal dari luar atau faktor eksternal. Pada penelitian ini disampaikan mengenai faktor internal yang dapat mempengaruhi partisipasi, diantaranya adalah usia, tingkat pendidikan dan jumlah tanggungan keluarga.

\section{Hubungan Usia dengan Tingkat}

\section{Partisipasi}

Responden dengan rentang usia 18 -

29 tahun yang memiliki tingkat partisipasi tinggi 4 orang atau 57,14 persen dari 7 orang responden pada kategori dewasa awal dan 3 orang atau

42,86 persen pada tingkat partisipasi sedang dengan kategori dewasa awal, kemudian tidak ditemukan responden dengan rentang usia 18 - 29 tahun dengan partisipasi yang rendah. Selanjutnya yaitu responden dengan usia 30 - 50 tahun yang memiliki tingkat partisipasi yang tinggi 10 orang atau 50,00 persen dari 20 orang pada kategori dewasa pertengahan, kemudian yang memiliki tingkat partisipasi yang sedang 10 orang atau 50,00 persen, dari 20 orang pada kategori dewasa pertengahan dan tidak ditemukan responden dengan rentang usia 18 - 29 tahun dengan partisipasi yang rendah. Kemudian untuk responden yang berusia >50 tahun dengan tingkat partisipasi yang tinggi 3 orang dari 3 orang responden pada kategori usia dewasa akhir atau 
100,00 persen, sedangkan pada tingkat partisipasi sedang dan rendah tidak ditemukan. Berdasarkan hasil uji korelasi Rank Spearman menunjukkan nilai koefisien korelasi 0,201. Hasil yang positif menunjukkan hubungan antara usia responden dengan tingkat partisipasi. searah. Semakin tua usia responden maka semakin tinggi tingkat partisipasinya. Nilai signifikansinya adalah 0,286 dimana hal ini lebih besar dari taraf nyata 0,05 . Berarti hubungan antara usia responden dengan tingkat partisipasi dalam Program Optimalisasi Pemanfaatan Lahan Pekarangan Melalui Konsep Kawasan Rumah Pangan Lestari ini tidak signifikan/tidak nyata

\section{Hubungan Tingkat Pendidikan} dengan Tingkat Partisipasi

$$
\text { Responden }
$$

dengan

Pendidikan Dasar

(SD/MI,SMP/MTs)

yang memiliki tingkat partisipasi tinggi 15 orang atau 55,56 persen dari 27 orang dan 12 orang atau 44,44 persen pada tingkat partisipasi sedang, kemudian tidak ditemukan responden dengan partisipasi yang rendah. Selanjutnya yaitu responden dengan Pendidikan Menengah (SMA/SMK/MA) yang memiliki tingkat partisipasi yang tinggi
1 orang atau 50,00 persen dari 2 orang, kemudian yang memiliki tingkat partisipasi yang sedang 1 orang atau 50,00 persen dari 20 orang dan tidak ditemukan responden dengan partisipasi yang rendah. Selanjutnya untuk responden yang dengan Pendidikan Tinggi (D3/S1) yang memiliki tingkat partisipasi yang sedang 1 orang atau 100,00 persen dari 1 dan tingkat partisipasi tinggi serta rendah tidak ditemukan. Hasil uji korelasi Rank Spearman memperlihatkan nilai koefisien korelasi 0,232 . Hasil yang positif menunjukkan hubungan antara tingkat pendidikan responden dengan tingkat partisipasi searah. Nilai signifikansinya adalah 0,286 dimana hal ini lebih besar dari taraf nyata 0,05. Berarti hubungan antara usia responden dengan tingkat partisipasi dalam Program Optimalisasi Pemanfaatan Lahan Pekarangan Melalui Konsep Kawasan Rumah Pangan Lestari ini tidak signifikan/tidak nyata

\section{Hubungan Tanggungan Keluarga dengan Tingkat Partisipasi}

Responden dengan jumlah tanggungan $2-3$ orang yang memiliki tingkat partisipasi tinggi 8 orang atau 72,73 persen dari 11 orang dan 3 orang atau 27,27 persen pada tingkat partisipasi sedang, kemudian tidak 
ditemukan responden dengan partisipasi yang rendah. Selanjutnya yaitu responden dengan jumlah tanggungan 4

-5 yang memiliki tingkat partisipasi yang tinggi 7 orang atau 38,89 persen dari 18 orang, kemudian yang memiliki tingkat partisipasi yang sedang 11 orang atau 61,11 persen dari 18 orang dan tidak ditemukan responden dengan partisipasi yang rendah. Selanjutnya untuk responden yang dengan jumlah tanggungan 6 - 8 yang memiliki tingkat partisipasi yang tinggi 1 orang atau 100,00 persen dari 1 dan tingkat partisipasi tinggi serta tingkat partisipasi rendah tidak ditemukan. Sehingga tidak ada kecenderungan hubungan antara tingkat Jumlah tanggungan keluuraga dengan tingkat partisipasi.

Berdasarkan hasil uji korelasi Rank antara Status/jabatan responden denganSpearman menunjukkan nilai koefisien korelasi -0,172,. Hasil yang negatif menunjukkan hubungan antara Jumlah tanggungan keluarga responden dengan tingkat partisipasi tidak searah. Nilai signifikansinya adalah 0,364 dimana hal ini lebih besar dari taraf nyata 0,05. Berarti hubungan antara usia responden dengan tingkat partisipasi dalam Program Optimalisasi Pemanfaatan Lahan Pekarangan Melalui Konsep Kawasan
Rumah Pangan Lestari ini tidak signifikan/tidak nyata.

\section{Hubungan Status/Jabatan dengan}

\section{Tingkat Partisipasi}

Responden status sebagai anggota yang memiliki tingkat partisipasi tinggi 10 orang atau 43,48 persen dari 23 orang dan 13 orang atau 56,52 persen pada tingkat partisipasi sedang, kemudian tidak ditemukan responden dengan partisipasi yang rendah. Selanjutnya yaitu responden dengan status sebagai pengurus yang memiliki tingkat partisipasi yang tinggi 6 orang atau 85,71 persen dari 7 orang, kemudian yang memiliki tingkat partisipasi yang sedang 1 orang atau 14,29 persen dari 7 orang dan tidak ditemukan responden dengan partisipasi yang rendah. Sehingga tidak ada kecenderungan hubungan antara Status/Jabatan dengan tingkat partisipasi.

Berdasarkan hasil uji korelasi Rank Spearman menunjukkan nilai koefisien korelasi +0,321. Hasil yang positif menunjukkan hubungan tingkat partisipasinya searah. Nilai signifikansinya adalah 0,084 dimana hal ini lebih besar dari taraf nyata 0,05 . Berarti hubungan antara usia responden dengan tingkat partisipasi dalam Program Optimalisasi Pemanfaatan Lahan Pekarangan Melalui 
Konsep Kawasan Rumah Pangan Lestari ini tidak signifikan/tidak nyata.

\section{KESIMPULAN DAN SARAN}

\section{Kesimpulan}

Berdasarkan hasil penelitian dan

pembahasan, maka dapat diambil kesimpulan sebagai berikut :

1. Karakteristik responden berusia diantara 30-50 tahun, tingkat pendidikan anggota sebagian besar $(90,00 \%)$ telah menempuh Pendidikan Dasar (SD/MI,SMP/MTs), jumlah tanggungan sebagian besar $(40,00 \%)$ antara $2-3$ orang, dan status atau jabatan dalam Kelompok Wanita Tani (KWT) Mekarwangi ada dua kategori jabatan yaitu sebagai anggota $(76,67 \%)$ dan sebagai pengurus $(23,33 \%)$.

2. Tingkat partisipasi anggota Kelompok Wanita Tani (KWT) Mekarwangi pada tahap pengambilan keputusan termasuk dalam kategori sedang, sementara pada tahap pelaksanaan, menikmati hasil dan tahap evaluasi termasuk dalam kategori tinggi.

3. Hubungan karakteristik responden yaitu usia, tingkat pendidikan, jumlah tanggungan keluarga dan status tidak memiliki hubungan nyata dengan tingkat partisipasi anggota dalam Program Optimalisasi Pemanfaatan Pekarangan melalui Konsep kawasan Rumah Pangan Lestari.

\section{Saran}

1. Berdasarkan kesimpulan diatas, maka saran yang dapat diberikan adalah :

2. Tingkat partisipasi dalam pengambilan keputusan perlu ditingkatkan yaitu dengan aktif mengikuti rapat, keaktifan dalam memberikan pendapat, memberikan pertanyaan, maupun memberikan kritik.

3. Anggota kelompok wanita tani (KWT) Mekarwangi sebaiknya mempertahankan bahkan meningkatkan tingkat partisipasi dalam setiap kegiatan baik itu program yang berasal dari bantuan pemerintah maupun kegiatan swadaya.

\section{DAFTAR PUSTAKA}

Arikunto, S.2010. Prosedur Penelitian. Suatu Pendekatan Praktek.Rineka Cipta.Jakarta

Ashari, Saptana, Tri B.Purwantini. 2012.Potensi Dan Prospek Pemanfaatan Lahan Pekarangan Untuk Mendukung Ketahanan Pangan.Pusat Sosial Ekonomi dan Kebijakan Pertanian. 
Badan Ketahanan Pangan, 2017. Pedoman Teknis Optimalisasi Pemanfaatan Lahan Pekarangan Melalui Kawasan Rumah Pangan Lestari Tahun 2017, Jakarta.

Badan Ketahanan Pangan, 2017. Petunjuk Teknis OptimalisasiPemanfaatan Lahan Pekarangan Melalui Kawasan Rumah Pangan Lestari Tahun 2018, Jakarta.

Badan Penelitian dan Pengembangan Pertanian, 2012. Pedoman Umum Pengembangan Kawasan Rumah Pangan Lestari (KRPL), Jakarta.

Damanik, D.2014. Hubungan Antara Karakteristik Petani Peternak Sapi Dengan Kinerja Penyuluhan (Kasus: Desa Ara Condong, Kecamatan Stabat Kabupaten Langkat).Jurnal Tentang Ekonomi Sosial Pertanian Dan Pertanian.Vol 3. No. 5 Mei 2014.

Daniel, M. 2003.Metode Penelitian Sosial Ekonomi.Bumi Aksara.Jakarta

Dinas Pertanian dan Ketahanan Pangan Kabupaten Ciamis. 2018. Data Kelompok Wanita Tani di Kabupaten Ciamsi Tahun 2017.Ciamis.

Dinas Pertanian dan Ketahanan Pangan Kabupaten Ciamis. 2018. Data Kelompok Pelaksana Program Optimalisasi Pemanfaatan Lahan Pekarangan Melalui Kawasan Rumah Pangan Lestari (KRPL) Kabupaten Ciamis Tahun 2107.Ciamis.

Mantra.2000.Demografi

Umum.UI Press.Jakarta

Mardiharini,M. 2011. Model Kawasan Rumah Pangan Lestari dan Pengembangannya ke Seluruh Provinsi di Indonesia. Warta Penelitian dan Pengembangan Pertanian,33(6):3-5.Badan penelitian dan Pengembangan Pertanian.
Misbahuddin, Hasan I. 2004. Analisis Data Penelitian dengan Statistik Edisi Ke-2.Jakarta.Bumi Aksara.

Mugniesyah SS. 2006. Pendidikan orang dewasa.Institut Pertanian Bogor. Bogor

Mukti S. 2013. Kondisi Sosial Ekonomi dan Modal Sosial Pada Berbagai TingPartisipasi Peserta Program Pos Pemberdayaan Keluarga. [Skripsi]. [Intern[diunduh 2019 Juni 11] Tersedia pada: http://repository. ipb.ac.id/handle/123456789/66066

Nababan.2013. Hubungan Karakteristik Penyuluh Pertanian PNS Terhadap Keberhasilan Penyuluhan (Kasus: Kecamatan Sunggal Dan Kutalimbaru Kabupaten Deli Serdang). Jurnal Tentang Ekonomi Sosial Pertanian Dan Pertanian.Vol.2 No.10 Oktober 2013

Nasdian FT. 2014. Pengembangan Masyarakat. Yayasan Pustaka Obor Indonesia. Jakarta.

Nazir, Mohammad,Ph.D.2011. Metode Penelitian. Ghalia Indonesia. Jakarta

Ningrum HA. 2014. Partisipasi masyarakat dalam program nasional pemberdayaan masyarakat mandiri (PNPM Mandiri) di Kelurahan Karang Anyar Samarinda Ulu. eJournal Sosiologi [Internet]. [diunduh pada 2019 Mei 11]; 02(3): 1-24. Tersedia pada: ejournal.sos.fisip- unmul.ac.id

Riduwan. 2012. Dasar-dasar Statistika. Afabeta. Bandung.

Rosyida I, Nasdian FT. 2011. penyelenggaraan program Coorporate Social Responsibility (CSR) dan dampaknya terhadap komunitas perdesaan. Sodality [Internet]. [diunduh 2019 Juni 11. Tersedia pada 
http://journal.ipb.ac.id/index.php/ sodality/article/view/5832

Santoso, S. 2012. Aplikasi SPSS pada Statistik Non Parametrik. Elex Media Komputindo. Jakarta. Saptana,

S.Friyatno.2013.Prospek Sunarsih, Pengembangan Model Kawasan Rumah Pangan Lestari dan replikasi pengembangan

KRPL.Pusat Sosial Ekonomi dan Kebijakan Pertanian.

Sudjana. 2005. Metode Statistika. Tarsito. Bandung.

Sugiyono. 2012. Metode Penelitian Kuantitatif, Kualitatif dan R\&D. Alfabeta. Bandung.
Sumaryadi, I Nyoman.2010.

Perencanaan Pembangunan Daerah Otonom dan Pemberdayaan Masyarakat. Jakarta: Penerbit Citra Utama

Tjasyono, B., 2004. Klimatologi.ITB. Bandung.

Yaningwati. 2007. Pemberdayaan SDM Perempuan pada Sektor Agribisnis. Jurnal Administrasi Bisnis 1. Yunitasari, N.2017.Hubungan Tingkat Partisipasi Dengan Tingkat Keberhasilan Program Desa Mandiri Pangan.Jurnal SKPM Vol.2(3).Departemen SKPM-IPB.Bogor. 